\title{
A função educativa da ginástica na República de Platão ${ }^{1}$
}

\section{Universidade Federal do Rio de Janeiro}

\section{Resumo}

Este trabalho argumenta que há dois conceitos de ginástica envolvidos na proposta educativa da República de Platão: a ginástica da temperança e a ginástica para a coragem. A ginástica da temperança é uma autoeducação sobre o cuidado do corpo. Ela depende da educação pela poesia e consiste em um regime pessoal. Todos os cidadãos devem praticá-la. A ginástica para a coragem é uma prática funcionalmente especializada dos guardiões e consiste em treinamento atlético. Ela visa o fortalecimento da parte impetuosa e a preparação para o regime de resistência que lhes é demandado ao longo de toda a vida.

Palavras-chave: Platão; República; Ginástica.

\begin{abstract}
This paper argues that there are two concepts of gymnastics involved in the educational proposal of Plato's Republic: the gymnastics of temperance and the gymnastics for courage. The gymnastics of temperance is a self-education about the caring for the body. It depends on the poetical education and consists in a personal regimen. All the citizens shall engage in it. The gymnastics for courage is a functionally specialized practice of the guardians that consists in an athletic training. It aims at strengthening the impetuous part of the soul and preparing them for the regimen of resistance required throughout their lives.
\end{abstract}

Keywords: Plato; Republic; Gymnastics.

1 Uma primeira versão deste texto foi apresentada em seminário promovido pelo Programa de Pós-graduação em Filosofia da Universidade Federal Rural do Rio de Janeiro em 04 de junho de 2014 e muito se beneficiou dos comentários então feitos pelos professores Alice Haddad e Admar Costa, a quem gostaria de agradecer.

Filosofia e Educação [RFE] - Volume 9, Número 1 - Campinas, SP

Fevereiro-Maio de 2017 - ISSN 1984-9605 - p. 131-164 


\section{Propósito}

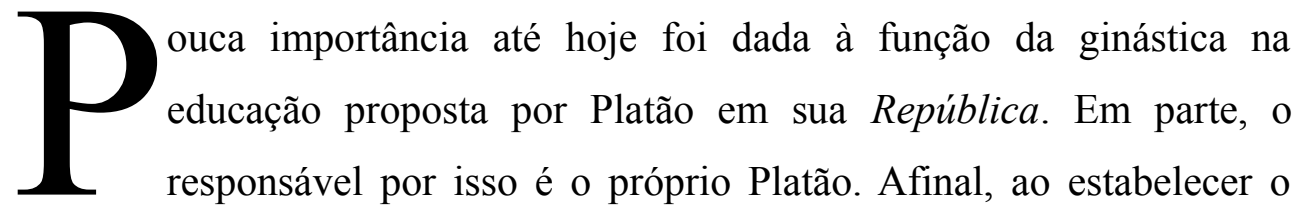
melhor padrão de educação, a fórmula é apresentada da seguinte maneira: "Qual será então a educação? Ou será difícil descobrir uma melhor do que a que descobrimos ao longo de muito tempo? Essa em suma é a ginástica para o corpo e a música para a alma”. (Platão, República, 376e1-3). ${ }^{2}$ A paideía tradicional é aqui apenas provisoriamente ratificada, a título de investigação. Não obstante, a imediata e extensa análise da função educativa da música que se segue induz o leitor a supor que a ginástica cuida de um elemento meramente secundário à educação. Acrescente-se a isso o fato de que Sócrates postula a debilidade do corpo enquanto agente educativo:

A mim não parece que um corpo são torne a alma boa em relação à sua excelência própria, mas o contrário: a alma boa, por sua excelência própria, mantém o corpo em seu melhor estado. A ti o que parece?

Também a mim, disse ele, parece assim.

Será então que agiríamos corretamente se transmitíssemos suficientemente o cuidado com o discernimento e deixássemos a ele a função de analisar com rigor as coisas do corpo de acordo com os moldes que nós dissermos que devem ser seguidos, a fim de não estender demais o nosso discurso?

É muito correto. (403d2-e3)

2 Todas as referências somente numéricas que seguem remetem à República de Platão, edição Slings, 2003.

Filosofia e Educação [RFE] - Volume 9, Número 1 - Campinas, SP

Fevereiro-Maio de 2017 - ISSN 1984-9605 - p. 131-164 
A leitura mais apressada dessa passagem diria que o cuidado do corpo seria uma simples consequência do cuidado com a alma, mais especificamente uma consequência da boa formação do discernimento (diánoia). ${ }^{3}$ Essa parece ser a posição da status quaestionis, como retratada por Gastaldi que, chamando a atenção para a desproporção entre os tratamentos da poesia e da ginástica na República, conclui afirmando que "as práticas realizadas pela obtenção da harmonia da alma obtêm um desenvolvimento ótimo do corpo"4. Este trabalho tem por propósito contestar essa simplificação da questão e especificar a função educativa da ginástica segundo a República de Platão. Ele defende que há dois conceitos de ginástica envolvidos nos processos educativos aí propostos, um primeiro, que chamarei de ginástica da temperança e um segundo que chamarei de ginástica para a coragem.

No que se segue argumento, sobre a ginástica da temperança, que: (i) trata-se de uma autoeducação, nisso diferindo da educação pela poesia, da qual ela depende por princípio; (ii) é um regime pessoal de vida que decorre de um caráter temperante; (iii) ao contrário da educação segundo funções que encontramos postulada na República, essa é uma prática não especializada, referindo-se ao cuidado dos seres humanos em geral com o

3 Entendo que a intepretação de Burnyeat sobre a diánoia em 475d estende-se também a essa passagem: "Quando Sócrates fala em pensamento (diánoia) nessa passagem, ele claramente tem em mente não pensamentos isolados que nos ocorrem ("Esse é um belo quadro!"), mas um estilo de pensamento que perpassa toda a vida do indivíduo e estrutura a sua perspectiva do mundo própria." (Burnyeat, 1997, 227)

4 Gastaldi, 1998, p. 388. Os clássicos também decepcionam sobre esse tema. Jaeger (2003, 795-801), por exemplo, afirma que a finalidade da ginástica é desenvolver a coragem do guerreiro e supõe que isso seja capaz de explicar como esse propósito dispensaria a cidade de médicos. O mesmo problema se encontra em Marrou. Ele argumenta que, em reação ao espírito de competição que tradicionalmente guiava a ginástica, Platão pretende revertê-la à sua finalidade original, que é a preparação à guerra. Porém, ele também nota que Platão quer "devolver ao esporte seu valor propriamente educativo, sua vertente moral, seu papel na formação do caráter e da personalidade, em pé de igualdade e em colaboração com a cultura intelectual". (Marrou, 1948, p. 115)

Filosofia e Educação [RFE] - Volume 9, Número 1 - Campinas, SP

Fevereiro-Maio de 2017 - ISSN 1984-9605 - p. 131-164 
seu corpo. Já sobre a ginástica para a coragem, pretendo mostrar que (iv) é uma prática funcionalmente especializada dos guardiões, à medida em que é um método educacional da parte impetuosa (thumós) da alma por meio de exercícios atléticos, e finalmente que (v) o desenvolvimento do ímpeto obtido por ela tem como propósito tornar os guardiões aptos a um regime de vida distinto do da temperança, aqui chamado de regime da resistência.

\section{A autoeducação}

Comecemos por analisar a longa citação apresentada na seção anterior. Já nessa passagem, que parece tão clara, algo desconcerta o leitor. Ao longo dos livros II e III da República, os moldes (túpoi) educacionais aparecem como regras estabelecidas pelos legisladores para a composição da poesia, de modo a delimitar o campo produtivo do poeta, ou seja, incumbi-lo de uma função (érgon) própria que é a educação básica desde a infância (cf. 378e7-379a4, 377a2-10). Porém agora, em nossa passagem, os moldes passam a reger o cuidado com o corpo por intermédio de um discernimento bem educado. De quem é esse discernimento? A valer o padrão até aqui tomado, os moldes se refeririam à delimitação da função do professor de ginástica. ${ }^{5}$ No entanto, a única menção a um paidotriba em toda a discussão sobre a ginástica parece desautorizar essa suposição. Ela se refere a Heródico.

A maior parte dos especialistas entende tratar-se do mesmo personagem citado por Protágoras, no Protágoras de Platão que, nascido em Mégara, estabelece-se em Selimbria, na Trácia. ${ }^{6}$ Este é, segundo Protágoras,

5 Sobre a prática profissional do paidotriba e do gumnastes, cf. Gardiner, 1955, p. 85-90.

6 Desde a Antiguidade há uma polêmica sobre a diferenciação entre Heródico de Selimbria e Heródico de Cnidos. O Anonymus Londiniensis atribui a Heródico de Cnidos uma refinada teoria de que a origem da doença estaria nos resíduos dos nutrientes (Anonymus Londiniensis, De Mecidina, IV 40-V 34), o que parece aproximá-lo da dietética associada a Heródico de Selimbria. Heródico é também mencionado no tratado hipocrático Epidemias,

Filosofia e Educação [RFE] - Volume 9, Número 1 - Campinas, SP

Fevereiro-Maio de 2017 - ISSN 1984-9605 - p. 131-164 
o criador da arte da ginástica, que o sofista de Abdera (ou ironicamente o autor Platão) associa ao que ele considera ser uma sofística avant la lettre (cf. PLATÃO, Protágoras, 316d9-e1). Platão volta a mencioná-lo no início do Fedro, 227d2-5, indicando sua recomendação de longas caminhadas, longas a ponto de se estenderem ida e volta de Atenas a Mégara, ou seja, algo em torno de 100 quilômetros. Aqui na República, ele é apresentado como um paidotriba que teria estabelecido todo um método misto de ginástica e medicina para prolongar a sua vida acometida de doença (406a5b2). Sócrates refere-se a essa prática de modo fortemente crítico: apesar de aparentemente ter encontrado uma forma de sobrevivência, esta demandava tamanha ocupação cotidiana com o seu corpo que toda a sua vida passou a se restringir a essa prática. Ao não ter mais qualquer ócio, o que Heródico conseguiu foi, ao invés de uma extensão da vida, uma extensão da sua morte (406b4-8) : uma vida longa não é uma boa vida.

O ócio é condição para a boa vida e, no contexto da República, isso faz dele uma das razões pelas quais a especialização profissional promove maior felicidade: ao dedicarmo-nos a uma só função, não apenas podemos dedicar maior atenção às tarefas, mas também resguardar o nosso ócio. É o que diz Sócrates ao estabelecer os princípios de fundação de uma cidade: "Em decorrência disto, cada coisa é produzida com maior quantidade, qualidade e facilidade quando um só indivíduo a faz de acordo com a sua natureza [individual] e com o momento oportuno, deixando o restante ao ócio" (370c4-6). ${ }^{7}$ O tipo de treinamento para a saúde formulado por Heródico não distingue função de ócio e, pior, opta por um cotidiano que não se dedica a nenhum dos dois. Ser um paidotriba à la Heródico é

VI, 3, 18 por matar pacientes com febre ao fazê-los correr, lutar e tomar banhos quentes. 7 Sobre a função do ócio na divisão das funções, cf. Araújo, 2016, p. 95-101.

Filosofia e Educação [RFE] - Volume 9, Número 1 - Campinas, SP Fevereiro-Maio de 2017 - ISSN 1984-9605 - p. 131-164 
portanto uma dupla afronta aos princípios de felicidade supostos na República.

Voltaremos ao problema de Heródico adiante. Por ora é importante entender que Sócrates tem razões para combater a especialização desse tipo de paidotriba, o que sugere enfaticamente que o discernimento que estabelece a aplicação dos moldes poéticos deve ser o do indivíduo que cuida de seu próprio corpo. Acrescente-se a isso o fato de que Sócrates, ao expor o que seriam os moldes da ginástica a serem seguidos pelo discernimento, não fala de métodos ou técnicas, mas de regras de comportamento transmitidas diretamente dos legisladores aos educandos, como, por exemplo, dizendo: "nós diremos que eles devem evitar a embriaguez" (403e4). Essa passagem é especialmente relevante para negar a especialização da ginástica, dado que, à fórmula citada, Gláucon reage dizendo: "pois seria ridículo que o guardião precisasse de um guardião" (403e7). ${ }^{8}$ Ao que podemos ver, é o inalienável discernimento do próprio educando que será responsável pela sua ginástica.

Assim, nossa citação introdutória sugere que, ao aprendermos cada um de nós os moldes da virtude que nos chegam por meio da educação poética, desenvolveremos o nosso discernimento e, pela sua aplicação às questões do nosso corpo, faremos boas escolhas. A rejeição à figura do paidotriba tal como encarnada em Heródico é uma rejeição a ações especializadas sobre corpos alheios, e a sugestão é de que a ginástica seja um cuidado do próprio corpo que segue como uma consequência prática da educação poética. Creio com isso poder defender a minha primeira tese, a de que aqui tratamos de uma educação pela ginástica que, diferentemente da

8 Confira também a fórmula no desafio de Adimanto: "Se nos fosse assim dito desde o início por todos vós e desde jovens tivésseis nos persuadidos, não seríamos os guardiões uns dos outros para que não cometêssemos injustiça, ao contrário, cada um seria o seu próprio melhor guardião, por receio de que, se cometesse uma injustiça, teria que conviver com o maior dos males". (367a1-5)

Filosofia e Educação [RFE] - Volume 9, Número 1 - Campinas, SP

Fevereiro-Maio de 2017 - ISSN 1984-9605 - p. 131-164 
educação pela poesia, é uma autoeducação. Por autoeducação entendo uma interpretação pessoal dos padrões da educação pública que aplica regras gerais ao corpo do indivíduo que as interpreta.

\section{A temperança}

Da tese de que a ginástica é uma forma de autoeducação podemos concluir que não é um mero acaso que a ginástica seja posterior à música (376e5-7). Platão sabe ser iconoclasta quando padrões atuais lhe parecem carecer de justificativa, e o fato de que usualmente os meninos iam ao ginásio aos sete anos, mas já ouviam poesia de suas amas desde bebês (377a5-6), não bastaria para lhe convencer de que este fosse o melhor procedimento. A ginástica como autoeducação é posterior à poesia por uma razão bem clara: como mostra a nossa passagem, ela supõe a formação do discernimento que se forma a partir da educação poética.

A melhor ginástica é irmã da música simples e sóbria (404b5-9), que, por sua vez, é aquela que não apenas tem mínima variação rítmica e harmônica (397b6-10), como tem por objeto de imitação o caráter sóbrio (397d4). Sobre este último, aprendemos no livro X, que ele é marcado pela estabilidade, pela tranquilidade e imperturbabilidade diante das circunstâncias externas (cf. 603e4, 604b7-c3 e 605d7-e1). ${ }^{9}$ Esse tipo musical foi proposto com base no princípio de que as imitações que permanecem desde a infância acabam por estabelecer o hábito e a natureza em relação ao corpo, à voz e ao discernimento (395c8-d3).

Ao tratar de como se aprende ginástica a partir da poesia, Sócrates fará o surpreendente movimento de afirmar que aí deveríamos nos basear em Homero (404b11), em detrimento da poesia mélica. Nos symposia, lar

9 A sobriedade aponta para um tipo de virtude não filosófica nos moldes que, adiante, veremos associada à temperança. Cf. Ferrari, 2012, p. 107-108.

Filosofia e Educação [RFE] - Volume 9, Número 1 - Campinas, SP

Fevereiro-Maio de 2017 - ISSN 1984-9605 - p. 131-164 
por excelência da poesia mélica e das músicas que suscitam relaxamento e sensualidade, imperam a culinária sofisticada, a pâtisserie e as prostitutas (404d1-e6). A contrastar com esse contexto, a poesia homérica, na sobriedade do gênero bélico, retrata como a guerra impõe um regime restrito à base da carne assada e da ausência de temperos (404b11-c10). A tese socrática então é que a poesia ensina a ginástica à medida que ensina o regime ou a dieta (diaité, cf. 404a5, 404d11, 406b7, 406d3, 406e-12, 407c9, 407d3-5, 408b1). Por regime, entendemos todo um modo de vida cotidiano que, certo, inclui a alimentação, os exercícios físicos, a higiene, mas que se expande muito além desses, constituindo-se por ações, costumes, padrões de comportamento e até sonhos que descrevem a rotina da vida de um indivíduo (cf. ek paídon dià biou - 403d1-2). ${ }^{10}$

A poesia ensina o regime de dois modos. No caso da menção a Homero esse ensino é feito pelo modelo proporcionado pelos personagens do poema: do que se alimentam, como se exercitam, etc. Nesse caso impera a clássica função emulativa da poesia sintetizada na máxima: "sempre o semelhante estimula o semelhante" (425c1-2). Porém a menção à poesia mélica sugere um outro modo como a poesia forma o nosso regime: aquele que se faz, não tanto por seus conteúdos, mas por sua harmonia e ritmo, e mais ainda, pelas práticas sociais em que essa formas musicais se inserem, ligadas à comida, à bebida e ao sexo. Ora, não é verdade que a poesia homérica está excluída dos symposia, em privilégio da mélica. Toda a poesia grega se envolve em contextos festivos que contrastam com os modelos de sobriedade que interessam a Sócrates. É evidente que no caso de uma rapsódia homérica em um banquete, os convivas, ao cantarem a alimentação frugal e restrita da guerra, encaixar-se-iam bem na clássica imagem aristotélica dos sonâmbulos, loucos e bêbados que recitam Empédocles, ou

10 Cf. Phillips, 1973, p. 78; Edelstein, 1994, p. 303-316.

Filosofia e Educação [RFE] - Volume 9, Número 1 - Campinas, SP

Fevereiro-Maio de 2017 - ISSN 1984-9605 - p. 131-164 
seja, os que não agem de acordo com o que dizem (Aristóteles, Ética a Nicômaco, 1147a19-23). A questão homérica é portanto mais complexa, antecipando de certo modo a sua expulsão no último livro, uma vez que a regra que o elege como o modelo para a ginástica é a mesma que demanda do educando que se resguarde das festas. Ainda assim, sigamos nossa análise textual:

Faríamos, creio eu, uma comparação correta se comparássemos toda essa culinária e esse regime à poesia mélica e às odes em toda sorte de harmonias e ritmos.

Como não?

Assim, onde a variedade gera o desenfreio há a doença; já a simplicidade gera, segundo a música, a temperança na alma e, segundo a ginástica, a saúde no corpo?

É a mais pura verdade. (404d11-e6)

Prestemos atenção à simetria da passagem citada: o desenfreio e a variedade referem-se ao regime produzido pela poesia mélica (cf. 404d1112), já a temperança aponta para o regime proposto pela poesia simples, que aqui encontra seu modelo no próprio Homero. Há bons e maus regimes poéticos. Porém o mesmo não ocorre com a ginástica: o regime da poesia mélica se transforma em doença, só a simplicidade permite a ginástica, e só a ginástica produz a saúde. Associe-se a essa passagem o que já aprendemos sobre a ginástica como autoeducação a partir do discernimento próprio. A conclusão, e a segunda tese deste trabalho, é a de que a ginástica é o regime individual e autodeterminado decorrente da temperança produzida pela emulação de um certo modelo poético. A poesia ensina a ginástica por ensinar a temperança. É assim que a música simples, ao formar o discernimento moldando-lhe segundo o que é melhor para o corpo, faz com 
que o indivíduo se determine a certos hábitos. É o exercício desse comportamento que promove o que é o melhor para o corpo que Sócrates entende por esse primeiro conceito de ginástica, que eu gostaria de chamar de ginástica da temperança.

Embora essa análise da ginástica se encontre no terceiro livro, ela já aponta para as duas definições de temperança que encontraremos no livro seguinte: a temperança política e a individual. ${ }^{11} \mathrm{~A}$ temperança de uma cidade consiste em uma ordenação política harmônica (431e7-8), fruto do governo do melhor (431b5-7), que é legitimado pela concordância de todos os cidadãos (431d9-e2). Nesse sentido, a temperança política é uma virtude distributiva: a cidade é temperante à medida que todos os seus cidadãos tornam-se ativamente parte da sua organização política (432a2-b1). Já a temperança individual, cuja definição evoca essa nossa discussão sobre o regime, consiste no autocontrole em relação a prazeres e desejos (430e4-6) que é obtido por uma concordância dos desejos e do ímpeto em se submeterem a motivações racionais $(442 \mathrm{c} 9-\mathrm{d} 2)$.

Entre os dois conceitos de temperança vemos apenas uma relação de analogia: a concordância entre os vários cidadãos de uma cidade é análoga a um equilíbrio das motivações internas de um indivíduo. ${ }^{12}$ Até aqui vimos que a ginástica se aplica à temperança individual, sendo uma prática que denota controle dos apetites e do ímpeto. Porém há também uma conexão entre esse tipo de prática e o conceito de temperança política. Para entendermos qual é ela devemos analisar o conceito de saúde que interessa a Sócrates ao postular uma educação da temperança. A saúde, a seu ver, não é algo com que naturalmente contamos, nem algo que nos acontece por acaso:

11 Sobre a importância da distinção entre as definições política e individual das virtudes no livro IV, cf. Demos, 1957, p. 170-174.

12 Para a centralidade do conceito de temperança no estabelecimento da relação analógica entre alma e cidade, cf. Rademaker, 2005, p. 294-295.

Filosofia e Educação [RFE] - Volume 9, Número 1 - Campinas, SP

Fevereiro-Maio de 2017 - ISSN 1984-9605 - p. 131-164 
precisamos nos educar para mantê-la. Porém, como já começamos a ver no caso de Heródico, Sócrates rejeita a produção da saúde por ofício e põe às claras a querela entre a filosofia e a prática da medicina.

\section{A universalidade}

A oposição à medicina é central para a compreensão da concepção platônica de ginástica. Em poucas palavras, a sua tese é de que a necessidade de médicos é signo de falta de educação (405a6-b4, cf. também 373d1-2). Sua proposta, já prenunciada em sua rejeição a Heródico, é abolir a face preventiva e dietética do exercício médico. A vinculação da saúde ao regime gerou uma corrente de prática médica que ganhou muita força no século $\mathrm{V}^{13}$, a ponto de, em certos tratados hipocráticos, encontrarmos a defesa de que essa constitui a verdadeira essência dessa ciência. Isso é, por exemplo, o que declara o autor de Da Antiga Medicina:

A tais descobertas e investigações que nome mais justo e adequado há de se dar do que medicina? Ela, que descobre sobre a saúde humana, sua nutrição e integridade, em oposição ao regime que antes gerava sofrimentos, doenças e morte. ([Hipócrates], De prisca medicina, $3.36-40) \cdot{ }^{14}$

Sócrates concorda com essa vertente médica ao defender que a saúde se origina do regime. Porém o seu ponto de discórdia está em que seja função da medicina tratar do regime humano. Ao contrário, é exatamente a proliferação de médicos especializados em dietética que Sócrates considera altamente vergonhosa. Não há que se tratar doenças originárias da preguiça

13 Para as divergências internas ao campo médico dos séculos IV-IV a.C., cf. Nutton, 2004, p. 43 e 97.

14 Cf. também [Hipócrates], De Arte, 6.

Filosofia e Educação [RFE] - Volume 9, Número 1 - Campinas, SP

Fevereiro-Maio de 2017 - ISSN 1984-9605 - p. 131-164 
e de um regime cotidiano viciado (405c7-d5). Também nesse caso Homero é a fonte inspiradora. Nele encontramos o modelo de uma prática austera de medicina que Sócrates atribui a Asclépio. Citando passagens homéricas, Sócrates ratifica-as como padrão para uma intervenção médica apropriada: aquela que se limita à traumatologia e à farmacologia de cura rápida (405d7406a4). Esse, o modelo antigo, foi corrompido por Heródico em sua dietética, resultando em uma influência perniciosa sobre a medicina hipocrática. A medicina Asclepíade, diz Sócrates, limita-se funcionalmente à intervenção curativa rápida devido, não à sua ignorância de meios ou incompetência em relação a processos, mas a uma justificativa política:

[Asclépio] sabia que a todos os que são bem governados, uma função é atribuída a cada cidadão, a qual necessariamente desempenham, e a ninguém é dado o ócio de adoecer e se tratar ao longo de toda a vida. Isso nós já percebemos como ridículo no caso dos trabalhadores, embora não o percebamos no caso dos ricos e dos aparentemente felizes. (406c3-8)

Como podemos ver, a tese sobre a função da medicina é política, ou seja, ela segue o padrão legislativo que define a função de cada cidadão segundo a sua natureza e resulta em consequências tanto para os médicos, quanto para os cidadãos em geral. No pano de fundo, vê-se a polêmica entre a expansão da classe dos trabalhadores a todos os cidadãos, defendida por Sócrates, e a medicina dietética. Afinal, é difícil compreender como um trabalhador poderia seguir a rotina indicada em alguns dos tratados hipocráticos, como por exemplo neste excerto de Sobre o Regime acerca das atividades invernais: 
No inverno convém resistir à estação fria e constringente pelo emprego do seguinte regime: Em primeiro lugar, é preciso fazer uma única refeição, caso não se tenha o ventre muito seco; neste caso convém um pequeno desjejum. No regime se utilizará do que é seco, adstringente, quente, não processado e sem mistura. Preferência será dada ao pão, às carnes assadas em detrimento das cozidas, e ao vinho negro, sem mistura e em pouca quantidade. O menos possível de legumes, à exceção dos quentes e secos, de suco e de sopa. Há que se dedicar a todos os exercícios e com muito esforço: corridas que aumentam em progressão, lutas que começam do mais leve impacto e aumentam continuamente. Caminhadas rápidas após o exercício no ginásio e lentas após o jantar. Pela manhã muito exercício (começando devagar, intensificando em seguida, e concluindo com serenidade). Convém dormir em leito duro, caminhar e correr à noite, pois tudo isso causa ressecamento e aquecimento. (De diaeta, III, 68, 12-28)

Tal como entendido pela tradição médica o regime capaz de proporcionar a saúde é uma ocupação de todo o tempo do dia, e por isso uma prática só viável à aristocracia. ${ }^{15}$ Mas a questão não é restrita a um problema de administração do tempo individual. Ao estabelecer a medicina como uma dietética, e a dietética como o modo de vida capaz de gerar o maior dos bens, a saúde, o médico toma para si a posição de conselheiromor ou, mais do que isso, a própria função da legislação. Não é outra a conclusão do autor de Sobre o Regime:

Isso eu aconselho à maioria dos seres humanos que, por necessidade, passam a vida a esmo, incapazes de, negligenciando tudo o mais, cuidar da própria saúde. Já àqueles que têm meios e reconhecem que

15 Cf. Phillips, 1973, p. 78; Edelstein, 1994, p. 304-305

Filosofia e Educação [RFE] - Volume 9, Número 1 - Campinas, SP

Fevereiro-Maio de 2017 - ISSN 1984-9605 - p. 131-164 
nada é mais útil que a saúde - nem a riqueza, nem todo o resto -, para esses há a dieta que eu descobri e que apresentei do modo mais rigoroso possível em relação à verdade" ([Hipócrates], De diaeta, III, $69,1-7)$

Esse tipo de concepção da boa vida é incompatível com a sua universalização a todos os cidadãos de uma cidade que precisa produzir os seus recursos. Ela supõe a divisão da cidade entre aqueles que podem e os que não podem dedicar-se à sua saúde. O Sócrates platônico é arguto ao assimilar esse tipo de regime, cuja origem ele enxerga em Heródico, à oposição entre meios de sobrevivência e virtude que se formula na máxima gnômica atribuída a Focílides: “depois que já se tenha de que viver, então exercitar a virtude" (407a8). ${ }^{16}$ Entretanto, ao invés de fazer questão sobre o sectarismo de tal tese da virtude, ele se propõe a mostrar que sequer no caso de uma plenitude de recursos, uma tal concepção de virtude poderia retratar a boa vida. A dietética médica, diz Sócrates, é uma nutriz de doença e essa nutrição impede o exercício intelectual (407b1-3). Dedicar os dias a algo que não seja o exercício da excelência é sinal de subserviência. Nesse caso, subserviência aos médicos, e paralização do uso do próprio discernimento para determinação dos padrões de regime do próprio corpo. A ginástica não pode ultrapassar determinados limites que impeçam o indivíduo do exercício de funções públicas e intelectuais por indisposição, cansaço ou letargia (407b6-c6).

Médicos não são legisladores e devem limitar-se a tratamentos por via de remédios e cirurgias que possam curar rapidamente os homens saudáveis e de regime equilibrado (408a6-b2). Como nenhum tratamento pode concorrer com o exercício da função, está justificada a eutanásia no

16 Focílides, vivendo em Mileto na primeira metade do sexto século a.C., teria escrito um poema gnômico em que daria conselhos a um jovem amigo. Cf. West, 1978, p. 167.

Filosofia e Educação [RFE] - Volume 9, Número 1 - Campinas, SP

Fevereiro-Maio de 2017 - ISSN 1984-9605 - p. 131-164 
caso dos incapazes de seguir o bom regime, os intemperantes (407e1-3, 409e4-410a4). Para um bom leitor está clara a estratégia: a medicina controla, por eliminação, o regime dos indivíduos. Não haverá cidadão intemperante na cidade simplesmente porque não lhe será oferecido tratamento às doenças que irremediavelmente irão lhe acometer. Pelo mesmo motivo não haverá cidadão que não execute uma função. Se o exercício de sua função não permite tratamento médico prolongado, ele precisa permitir, ou melhor, ele precisa exigir que cada cidadão pratique a ginástica, o substituto da medicina preventiva que é realizado não por um profissional, mas por cada indivíduo.

Vemos aqui como as duas teses socráticas sobre a saúde promovem a articulação compulsória, do contrário inexistente, entre temperança individual temperança política. Já vimos que indivíduos são temperantes à medida que controlam seus apetites e seu ímpeto no seu cuidado com o corpo, promovendo a sua saúde. Agora vemos que esses indivíduos também seguem esse regime de modo a obedecer a regra que funda a cidade e que consiste em que todos os cidadãos devam exercer uma função. Ao escolher o regime socrático em detrimento da dietética médica, esses cidadãos estão legitimando o princípio básico da cidade e demonstrando-se politicamente temperantes por concordarem com que este é o melhor governo. O regime proposto por Sócrates é determinado pelos dois conceitos de temperança. E porque ele visa a temperança política, ele precisa ser uma prática universal de todos os cidadãos.

Em sua análise da ginástica, Sócrates também combate o uso da ginástica como formação de atletas para competição. ${ }^{17}$ Estamos aqui falando não mais do cuidado com o corpo, mas da profissionalização do atleta, um fenômeno que ocorre a partir do século VI a.C., devido à grande

17 Sobre a profissionalização atlética, cf. Gardiner, 1955, p. 99-106.

Filosofia e Educação [RFE] - Volume 9, Número 1 - Campinas, SP

Fevereiro-Maio de 2017 - ISSN 1984-9605 - p. 131-164 
popularidade dos jogos e de seus vencedores. Os desportistas dedicam todo o seu dia ao exercício; são treinados para fins exteriores - competições, jogos - e para a condução do corpo não à saúde, mas ao seu extremo. O seu excesso de treinamento, diz Sócrates, gera sono, um obstáculo à percepção apurada e, o que é mais grave, qualquer alteração na sua rotina causa-lhe problemas de saúde (403e8-404a8). Tanto o atletismo como a dietética médica são práticas equivocadas da ginástica, porque não estão fundamentadas no princípio da autodeterminação do corpo pela regra da temperança. Mas esse não é o único argumento de Sócrates sobre a ginástica atlética e há mais problemas que nos aguardam a essa altura. Porém, antes de passar a eles, gostaria de concluir essa primeira parte, que trata da ginástica da temperança, com a proposta de minha terceira tese, a saber, que ela é uma prática não especializada comum a todos os cidadãos.

\section{A educação da alma do guardião}

Como mencionado, Sócrates usa um outro argumento contra o uso atlético da ginástica, bem distinto do que vimos. Ele trata do propósito dos exercícios físicos e, com isso, resguarda uma condição segundo a qual eles seriam benéficos à educação. Do indivíduo bem educado ele diz que: "exercita-se na ginástica e no esforço físico com vistas a esclarecer ${ }^{18}$ a natureza impetuosa, mais do que com vistas à força física, como pretende a alimentação e esforço dos demais atletas" (410b5-8). À primeira vista já entendemos que aqui - ao contrário do que vimos na primeira parte desse trabalho - Sócrates rejeita o padrão educacional tradicional da música para a

18 "Esclarecer" talvez seja uma tradução exagerada para egeíron, "acordar, tornar desperto". Porém essas opções levariam a uma confusão conceitual. O ímpeto é sempre presente em nós desde a infância e várias são as ocasiões em que é ativado. Não é como ativação do ímpeto que a ginástica funciona como exercício educacional, mas como vinculação do ímpeto à racionalidade, fazendo com que ele seja acionado por motivos justificados.

Filosofia e Educação [RFE] - Volume 9, Número 1 - Campinas, SP

Fevereiro-Maio de 2017 - ISSN 1984-9605 - p. 131-164 
alma e ginástica para o corpo, que havia sido provisoriamente ratificado. Contra os atléticos, mas também contra os dietéticos, a ginástica não deve ser vista como um modo de educação do corpo; ela educa uma das partes da alma: o ímpeto (thumós). Essa é uma guinada peculiarmente estranha no argumento sobre a ginástica. Não apenas porque ela parece recusar a tese bem argumentada da universalidade da educação da temperança, mas porque esse parece ser um ponto aceito apenas ad hoc. No livro VII voltaremos a ser informados de que a ginástica é uma educação para o corpo e as coisas que vêm a ser e perecem (521e1-2), ao passo que a música, sendo uma contra-força da ginástica, diz respeito à harmonia que forma o caráter (522a3-8). Como harmonizar essas duas compreensões de ginástica, uma que é decorrência sobre o corpo da educação poética para a temperança e outra que é contra-força da educação musical sobre a alma? A resposta é: trata-se de dois conceitos distintos com aplicações educacionais diferentes.

Voltemos à passagem de defesa da ginástica como educação da alma e notemos que aqui há uma requalificação do próprio conceito de ginástica. No primeiro argumento contra o modelo atlético (403e8-404a8) tratava-se de que ele não servia à finalidade da saúde que guiava a ginástica segundo o regime da temperança. Já nesse segundo argumento (410b5-412a8), o modelo atlético é recomendado exatamente pela promoção de uma certa brutalidade e rigidez que seriam convenientes à educação (410d1, compare com tò ágrion em $410 \mathrm{~d} 6$ e sklerô̂ em 411b1). Assim, a crítica ao atletismo não se refere exatamente ao seu propósito de produzir a força, mas ao fato de que a força que ele promove deve ser contrabalançada pela gentileza gerada pela educação musical. Quando estamos falando da função da ginástica enquanto educação da alma, estamos falando sim de padrões de exercício físico que extenuam o corpo, levando-o ao seu limite, com o fim, não da saúde, mas, como veremos na adiante, da formação da resistência.

Filosofia e Educação [RFE] - Volume 9, Número 1 - Campinas, SP Fevereiro-Maio de 2017 - ISSN 1984-9605 - p. 131-164 
Ao propor a ginástica como um meio de fortalecer o ímpeto, Sócrates nos remete ao segundo livro da República e à apresentação da figura do guardião. Nessa ocasião delineou-se o problema de sua educação à medida que, para que se cumpra a função de fazer a guerra (375a11-b1), o ímpeto é indispensável. Saberemos mais adiante na República que o ímpeto responde pelas motivações de raiva (orgé - 440a6, c1), indignação (khalepaíno - 440c7), persistência (hupoménein - 440d1), vitória (níke 440d1, 545a2) e honra (timé - 545a3, b6-7, 549a4). Entende-se facilmente porque essas sejam características identificadas ao bom desempenho de um soldado. No entanto, a função do guardião da cidade é dupla: cabe a ele também velar pela constituição da cidade justa e sua integridade. Para essa função, o ímpeto é um traço de caráter altamente arriscado, afinal, o ardor bélico pode se voltar contra o próprio exército e os seus próprios concidadãos (375b10-12). ${ }^{19}$ A solução encontrada por Sócrates então foi de que a função demandasse, para o seu exercício, indivíduos dotados não de uma (como o restante dos cidadãos, cf. 370b2-3), mas de duas naturezas anímicas: a impetuosa e a filosófica (375e9-10). À séria objeção de que esses dois caracteres seriam inconciliáveis, Sócrates responde meramente apontando para a existência de entes naturais, os cães de guarda, capazes de ser dóceis com os amigos e ferozes com os inimigos. É a esse problema que ele retorna o final do argumento sobre a ginástica nos sugerindo que a existência de indivíduos capazes de se tornar guardiões depende de um treinamento simultaneamente gímnico e filosófico (410d10-412a7). Para ser mais clara, como a ação impetuosa de um guardião tem efeitos sobre outros indivíduos (375b10-12), efeitos cuja justiça precisa ser salvaguardada, a educação musical universal já não bastará a esse indivíduo; é preciso que ele

19 Sobre o risco da educação do ímpeto, cf. Hobbs, 2000, p. 11.

Filosofia e Educação [RFE] - Volume 9, Número 1 - Campinas, SP

Fevereiro-Maio de 2017 - ISSN 1984-9605 - p. 131-164 
desenvolva o seu aprendizado racional de modo a identificar as circunstâncias a que dirigir o seu ímpeto (376b4-7).

O propósito educacional de uso da ginástica como contra-força que, combatendo uma moleza própria à natureza filosófica (410e1-2), harmoniza a alma (410e8, 412a4-5, 411e4-412a2), dialoga com uma temática em voga no século V. Ecos desse assunto encontramos na famosa oração fúnebre Péricles que, segundo Tucídides, assim definia o ideal ateniense:

Sobre a educação, enquanto eles [os Lacedemônios] desde muito jovens exercitam-se com esforço para tornarem-se corajosos, nós mantemos o regime maleável, sem com isso deixarmos de nos igualar a eles no enfrentamento dos perigos (...) Se então preferimos encarar o risco por meio da amenidade, ao invés do exercício do esforço, por meio da coragem do caráter, ao invés da lei, isso não nos torna superiores? Afinal, não antecipamos a dor futura e, ainda assim, quando chega a hora, não somos mais covardes do que aqueles que se extenuam sem cessar. É por isso que nossa cidade é digna de admiração tanto na guerra, quanto na paz. Somos amantes do belo com simplicidade e da sabedoria sem debilidade (philosophoûmen áneu malakías). (TUCÍDIDES, História da Guerra do Peloponeso, II, $39.2-40.1)$

A célebre oposição entre atenienses e espartanos é enunciada por Tucídides como a diferença entre uma educação do esforço físico e um regime de vida maleável. Péricles elogia os atenienses por serem capazes dos mesmos resultados bélicos que os lacedemônios sem submeterem-se à ginástica extenuante. Platão opõe-se a essa tese na República. Talvez justificada pelo próprio resultado da guerra do Peloponeso, sua posição é de que o regime maleável não garante resultados bélicos (373e10-374e4). Não

Filosofia e Educação [RFE] - Volume 9, Número 1 - Campinas, SP Fevereiro-Maio de 2017 - ISSN 1984-9605 - p. 131-164 
obstante, Platão continua forte defensor da máxima do amor à sabedoria sem debilidade (philosophoûmen áneu malakías), como veremos adiante. Ademais, ele também faz sua a tese de que a coragem de uma cidade emana do caráter e do modo de vida dos seus combatentes, embora com isso não rechace a contribuição da lei em promovê-la.

Tal como a temperança, a coragem também terá duas definições no livro IV. Do ponto de vista individual, a coragem é a integridade da parte impetuosa da alma em sua obediência aos princípios racionais, sobretudo em contextos que envolvem dor e prazer (442b5-c3). Por outro lado, a coragem se aplica a uma cidade à medida que os seus guardiões são capazes de manter a integridade das leis que constituem a sua educação, mesmo nas circunstâncias mais terríveis (429b1-430b9). A relação entre as duas definições de coragem é mais clara do que a relação entre as duas definições de temperança. A cidade é corajosa à medida que nela há guardiões exercendo bem a sua função. Os guardiões são corajosos à medida que têm ímpeto desenvolvido e obediente à razão. Pode haver complementariedade entre as duas se indivíduos corajosos forem designados como guardiões da cidade. A coragem individual depende da conciliação entre as educações gímnicas e filosófica. A coragem política depende de algo mais: depende de que os indivíduos assim educados sejam alocados em seus postos, ou seja, depende da lei, o fator a que Péricles se opunha e que, como veremos adiante, parece aproximar Platão dos lacedemônios.

Muitos foram os intérpretes que notaram que, ao finalmente tratar das virtudes cardinais na alma no livro IV, Sócrates mantém-se fiel ao usual argumento da unidade das virtudes. ${ }^{20}$ Ele parte do princípio de que alguém educado pela música e pela ginástica apresenta concordância interna em suas motivações (441e7-442b3), para mostrar que, neste indivíduo, a

20 Cf. por exemplo Demos, 1954, p. 172; Irwin, 1995, p. 236-239.

Filosofia e Educação [RFE] - Volume 9, Número 1 - Campinas, SP

Fevereiro-Maio de 2017 - ISSN 1984-9605 - p. 131-164 
coragem se identificará na integridade de seu ânimo (442b10-c3), a sabedoria no conhecimento do que convém a cada motivação e ao seu conjunto (442c4-8), a temperança na concordância dos desejos à regra da razão (442c9-d4) e finalmente a justiça no bom funcionamento de todas as suas motivações (443c9-444a2). Não obstante, o que nosso argumento mostra é que aqui é preciso reconhecer que, no que tange ao ímpeto, há dois padrões distintos de virtude, um indicado pela temperança, que, como vimos na primeira parte, atrofia-o pelo seu regime de vida, e um outro que, como começamos a ver agora, desenvolve-o. ${ }^{21}$ A coragem, diz Sócrates, é condição para se lutar bem e não há como ser corajoso sem um forte ímpeto (375a9-b1). Senão vejamos.

A prática da temperança de que falamos na seção anterior apontava para o modo como a gradual aquisição da racionalidade através da música controlava o ímpeto: sendo a temperança uma harmonização de todas as partes da alma, é preciso que não apenas os desejos, mas também o ímpeto sejam controlados pelo princípio racional (442c9-d2). Nesse modelo, a ginástica atuaria sobretudo como regime e cuidado do corpo que resultariam desse caráter. Sócrates almeja algo mais quando fala que a ginástica, e mais especificamente o treinamento atlético, deve ter como propósito fortalecer o ímpeto. Aqui não se trata mais de um cuidado pessoal com o próprio corpo, mas da superação, do aumento da resistência, da competição frente ao inimigo. Esses objetivos não devem ser confundidos com o do treinamento que tinha por objetivo a profissionalização atlética; eles são indícios da tentativa platônica de construir uma real relação entre ginástica e guerra.

21 Entendo que é a esse problema que se refere a noção de virtude popular (demotike areté) em $500 \mathrm{~d} 9$. Não se trata de uma distinção conceitual das virtudes, mas de uma distinção de grau. North (1966, p. 174) entende que se trata aqui de dois tipos de temperança. Entendo, ao contrário, que se trata da distinção entre graus de sabedoria, e que essa distinção se deve a um desenvolvimento mais agudo da racionalidade capaz de contrabalançar um desenvolvimento do ímpeto. Para outra evidência da questão confira o caso da "virtude sem filosofia" em 619c8.

Filosofia e Educação [RFE] - Volume 9, Número 1 - Campinas, SP

Fevereiro-Maio de 2017 - ISSN 1984-9605 - p. 131-164 
Como argumenta Golden (1998, p. 23-28), entre os séculos VI e IV a. C. deixa de haver uma relação entre guerra e ginástica, uma vez que o combate hoplita não demanda as habilidades desenvolvidas pelo treinamento. Nesse período a ginástica restringe-se ou ao cuidado da saúde ou à preparação para os jogos. Se prestamos atenção a esse cenário, entendemos que, com a proposta do desenvolvimento do ímpeto, Platão está sugerindo um novo propósito à ginástica: formar a coragem do guerreiro, e não sua habilidade. Aliás ele pretende mais do que isso: ele também quer mostrar como o ímpeto e a coragem são centrais ao exercício do governo.

Esse é o tema de nossa próxima seção. Neste momento, é preciso concluir explicitando a quarta tese deste trabalho: a ginástica como prática para a coragem compõe a educação para o desempenho da função política específica do guardião. Nisso ela é distinta - qualitativa e quantitativamente, em intensidade e em objetivo - da prática associada à temperança. Essa última é uma prática autodeterminada que decorre da aquisição da temperança, sua aplicabilidade é universal e visa o cuidado do próprio corpo pela aplicação dos modelos aprendidos pela poesia segundo os parâmetros de um regime de vida. Já a ginástica que é específica aos guardiões visa a educação da sua alma para a realização de sua função cívica, a guerra e o governo, que requerem a virtude da coragem. Essa ginástica não decorre da sua virtude, como a primeira, mas prepara para a virtude em uma prática que é, como veremos a seguir, determinada por padrões externos. Trata-se de exercícios físicos que, devido ao seu caráter extenuante, são inconvenientes aos cidadãos em geral e incompatíveis, em termos políticos, com um regime por toda a vida. 


\section{O regime da resistência}

Ao contrário da racionalidade, cujo desenvolvimento individual depende do resultado de uma educação musical (441a9, 401d4-402a4), o ímpeto é uma motivação presente nos seres humanos desde a primeira infância (441a7-8). O que o desenvolvimento da racionalidade faz é esclarecer o ímpeto (411d1$5)^{22}$, estabelecer bons propósitos para o seu acionamento e, assim, mantê-lo equilibrado (410e8, 411e7-412a8). Esse parâmetro vale tanto para a educação universal, quanto para a educação específica do guardião, mas ele naturalmente difere em intensidade e qualidade. Enquanto a educação poética parece bastar para a formação de um regime temperante, o controle de um ímpeto desenvolvido demanda também uma educação mais forte da racionalidade. É isso o que vemos indicado no currículo de formação do guardião apresentado no livro VII.

Ali Sócrates propõe que, ao final da educação básica, baseada na música simples e nos modelos de ginástica que seguem a temperança, ou seja, por volta dos 18 anos, aqueles e aquelas que demonstrarem competências afins à função de guardião devem dedicar-se dois a três anos exclusivamente à ginástica (537b1-5). Essa é a primeira etapa da educação que é restrita aos guardiões. Que se trate aqui de um contínuo treinamento atlético, nos moldes extenuantes que Péricles atribuía aos lacedemônios, fica claro pela nota de Sócrates de que durante esse período lhes é impossível realizar qualquer outra atividade ou aprendizado, já que isso seria incompatível com a fadiga e o sono que constantemente lhes adviriam (compare 404a1-4 e 537b3). Como vimos, uma das críticas feitas por Sócrates ao atletismo desse tipo dizia que o regime extenuante enfraqueceria a saúde, tornando os indivíduos inaptos a qualquer outro ambiente ou

22 Cf. em particular a ocorrência de egeirómenon em $411 \mathrm{~d} 4$ em comparação com $410 \mathrm{~b} 6 \mathrm{e}$ com a nota 18 deste trabalho.

Filosofia e Educação [RFE] - Volume 9, Número 1 - Campinas, SP

Fevereiro-Maio de 2017 - ISSN 1984-9605 - p. 131-164 
regime que não fosse aquele com o qual estão acostumados (404a4-b4). Ao recomendar o treinamento atlético aos guardiões, Sócrates precisa evitar esse tipo de enfraquecimento.

Quando procuramos elucidação sobre esse tipo de treinamento, não a encontramos na Politéia (República) de Platão, mas em uma outra: $A$ Constituição (Politeía) dos Lacedemônios de Xenofonte. Nosso melhor testemunho sobre a educação criticada por Péricles nos conta que os meninos educados pelo paidonómos espartano deviam andar descalços, para fortalecerem o caminhar e a corrida; usar uma só túnica o ano inteiro, a fim de resistirem tanto ao calor quanto ao frio; nunca comer até saciar a fome, para que se habituassem a treinar e trabalhar com o estômago vazio, e nunca se acostumar com determinados alimentos, para que se adaptassem melhor a situações adversas. A negação da saciedade teria também como propósito estimular a engenhosidade dos meninos em roubar comida, embora castigos físicos fosse aplicados aos que eram descobertos em tais práticas, sob a alegação de que haviam fracassado naquilo que precisavam aprender (Xenofonte, Constituição dos Lacedemônios, 2.3.1-2.8.5).

Schofield (2006, p. 37-40) sugere que qualquer leitor contemporâneo a Platão consideraria a cidade da sua República um regime de inspiração lacônica. Essa inspiração marca, segundo ele, o gênero literário das politeíai e, quando aplicada a Platão, leva seguramente a exageros. Muito do que já foi dito aqui marca a distinção entre os regimes lacônico e platônico. A ginástica como educação do ímpeto, entretanto, é um traço de sua aproximação. As condições muito específicas em que ela deve ser aplicada, por sua vez, indicam a estratégia platônica de se distanciar do laconismo. Por exemplo, ao limitar o treinamento atlético a dois ou três anos, Sócrates intenta prevenir alguns de seus malefícios, como veremos adiante. Por outro 
lado, ao defendê-lo, ele o faz exatamente pelos mesmos motivos espartanos: o fortalecimento da resistência (kartería). ${ }^{23}$

Resistência é a capacidade adquirida pelo fortalecimento do ímpeto (cf. kartería - 390d1) ${ }^{24}$ : aqui mais uma vez é de Homero que nos vem o modelo educacional, com uma passagem duas vezes citada na República (390d4-5 e 441b5). Odisseu, que vê suas escravas se deleitarem com os pretendentes de Penélope que devoravam suas riquezas, contém o seu ímpeto em função de seu raciocínio sobre o que é o melhor (441c1-2): "golpeia o peito e censura o coração com as palavras: 'resista, coração, já suportaste horrores maiores!'.”(Homero, Odisseia, XX, 17-18). Todos sabemos que Odisseu não deixará de cometer a violência que the parece adequada, mas ele a fará sob a égide de seu raciocínio. Para conquistar esse caráter que resiste a todas as demais alternativas e permanece resoluto na decisão sobre o melhor, há um procedimento educativo. Primeiramente a ginástica atlética desenvolve os sentimentos de raiva, indignação, persistência, vitória e honra ligados ao ímpeto. A seguir esses sentimentos são submetidos ao crivo do raciocínio, sobretudo, como veremos, por meio da provação. Da primeira parte desse sistema, como nos conta Xenofonte, os espartanos sempre foram senhores (cf. Xenofonte, Constituição dos Lacedemônios, 4.2.1-5, 12.5.3-4). O que eles não fizeram foi conjugar o teste de resistência com o teste de convicção justificada, e mais, não fizeram seguir desse desenvolvimento do ímpeto um desenvolvimento muito mais longo das capacidades intelectuais. Platão parece entender que o risco envolvido no desenvolvimento do ímpeto só é controlado pela sua

23 Sobre a centralidade da resistência como propósito da educação espartana, cf. Kennell, 1995, p. 111-114.

24 Cf. também a menção à resistência na escolha da harmonia dória para a música simples em 399b2, o que certamente trará à memoria a discussão sobre a resistência no Laques (Platão, Laques, 192b8-194b7)

Filosofia e Educação [RFE] - Volume 9, Número 1 - Campinas, SP

Fevereiro-Maio de 2017 - ISSN 1984-9605 - p. 131-164 
transformação em resistência ${ }^{25}$ e para isso é preciso continuar o currículo de formação do guardião.

Ao longo dos dois ou três anos de dedicação atlética à ginástica, os educandos serão testados e selecionados para a fase seguinte da sua educação: dez anos de aprendizado sobre a relação das matemáticas entre si de acordo com o padrão platônico de ensiná-las, com vistas a se elaborar a uma teoria da realidade (537b7-c3, compare com 523a1-3, 525b9-c7). Depois de dez anos de matemática platônica, apenas os capazes de ter uma visão conjunta desses aprendizados serão educados na dialética (537c6-7). O teste pretende ser muito rigoroso, selecionando aqueles que podem, não apenas dispensar a percepção em sua abordagem da verdade (537d5-7), mas que também tenham natureza ordenada e estável (539d4). O risco é de que, ao aprenderem a dialética, eles apliquem-na como um método de exame aos valores que fundamentaram a educação que receberam (compare tò kalón em 538d7 com 403c5), transformando-a em mera antilogia e pura refutação (539b1-6).

Uma vez demonstrado o seu caráter, é necessário que o aprendiz se dedique ao estudo da dialética pelo dobro do tempo de sua dedicação à ginástica. Isso porque, diz Sócrates, será esse o aprendizado que promoverá nele a contra-força capaz de equilibrar a hipertrofia do ímpeto nos anos de ginástica. Para tal tarefa, a educação poética é insuficiente. Apenas depois de que a dialética equilibre a ginástica atlética, aos trinta e cinco anos, é que os guardiões terão uma alma educada a ponto de ser exposta pela primeira vez à experiência da guerra e do governo (539e3-6). Sócrates é lacônico sobre como isso deveria acontecer. Ao que parece, todo o caminho que foi percorrido até aqui deve bastar para o sucesso dessa primeira experiência, ao

25 Cf. Hobbs, 2000, p. 12. Hobbs identifica muito rapidamente a resistência à coragem. Defendo aqui que a necessidade de um currículo filosófico distingue as duas etapas: a resistência é uma condição para a coragem.

Filosofia e Educação [RFE] - Volume 9, Número 1 - Campinas, SP

Fevereiro-Maio de 2017 - ISSN 1984-9605 - p. 131-164 
menos se considerarmos os apontamentos sobre a utilidade prática da matemática (525b1-c7). De todo modo, o sistema de testes continua durante esses anos de prática (539e6-540a2), purgando os fracassos profissionais tal com a medicina purgava os imoderados. Ao fim de quinze anos de prática militar e governamental, tem-se finalmente um governante e um filósofo.

A formação do guardião, porém, não começa aos dezoito anos, ela requer tanto a educação universal quando outras capacidades desenvolvidas nessa etapa. Na primeira infância as crianças em geral precisam ter contato com as primeiras noções da matemática (536d4-537a3). Além disso, República também apresenta uma peculiar descrição da educação infantil para a guerra (466e1-467a9). A formação do guerreiro se dá pela experiência (empeiríai), que como dissemos só pode ocorrer após o aprendizado da dialética, mas também pela contemplação (théai - 467a8), que deve começar desde muito cedo. Sócrates sugere que as crianças sejam levadas ao campo de batalha para assistir seus pais e mães em batalha. Sobre esse ato de contemplação Sócrates diz, talvez para o espanto de alguns acadêmicos contemporâneos, fazer parte da educação de qualquer artesão. Antes de qualquer coisa, os aprendizes de ceramista observam (467a2-5); eventualmente prestam pequenos serviços (467a1-2, 4), mas sempre mantendo a distância da observação, sem tocar na matéria-prima (467a4-5). Um guardião é, como todo cidadão na República, um artesão, e também sua educação deve seguir esse modelo. Esse exercício contemplativo da sua própria função futura, diz Sócrates, é fundamental (467c1-2; e4-6) a ponto de justificar o risco de que elas sejam mortas pelo inimigo (467b3-12). Para controlar esse risco, Sócrates sugere que elas aprendam a cavalgar desde muito cedo para poderem fugir com agilidade (467d10-e6).

No projeto da contemplação da guerra, assim como no de ensino lúdico da matemática, Sócrates também vê as primeiras ocasiões de seleção 
de indivíduos (537a1-2, 9-11). Os critérios dessa primeira seleção são, no primeiro caso, aptidão intelectual, e no segundo, o esforço, o aprendizado e o medo. Esses critérios de seleção persistem ao longo do currículo, aliandose a outros que lhes são congêneres e que já foram aqui sugeridos: força física (537b4-5), visão de conjunto (537c6-7), convicção sobre as crenças fundamentais de sua educação (538c6-8), ordenação e estabilidade de caráter $(539 \mathrm{~d} 4)$, bom desempenho bélico e político (539e6-540a2). Fica claro que esse sistema educacional se baseia no princípio que Sócrates anuncia quando de sua análise sobre a função educacional da ginástica, no livro III: os guardiões precisam ser postos à prova ao longo de toda a sua vida; os testes constituem elemento central em seu regime (412d9-e2).

Gostaria nesse momento de apresentar a quinta e última tese deste trabalho: a de que Sócrates introduz o treinamento atlético no início da formação exclusiva dos guardiões para torná-los aptos a um regime de vida baseado na resistência. Esse caráter não é importante ao guardião apenas por contribuir à sua excelência na batalha, ele é também um traço indispensável ao governante, referindo-se à convicção sobre o seu compromisso com a cidade. Estamos falando aqui de função educacional da ginástica inversa à do caso da temperança: não se trata de uma ação sobre o corpo que resulta da virtude anímica desse mesmo indivíduo, mas de um treinamento imposto por outrem que, por meio de exercícios físicos, produz a resistência como traço de caráter. A resistência não é uma virtude por si só, ela depende de que seus propósitos sejam bons. Nesse sentido, ela é um requisito para a coragem, que só é obtida quando esses propósitos são internalizados por meio de uma educação filosófica. Enquanto esse patamar não é alcançado, a resistência se vincula a crenças adquiridas sobre o que é o melhor e pode ser objetivamente testada como o grau de convicção a elas atribuído.

Filosofia e Educação [RFE] - Volume 9, Número 1 - Campinas, SP Fevereiro-Maio de 2017 - ISSN 1984-9605 - p. 131-164 
Vejamos com mais detalhes como os testes são propostos para medir a resistência dos guardiões. Aprendemos, ao fim do livro III, que os guardiões formam o grupo a partir do qual os governantes são escolhidos, não por eleição, mas por teste. Os governantes são os melhores dentre os mais velhos guardiões, tomando por critério a sua sensatez e o seu amor pela cidade (412b9-d8). Isso justifica que os guardiões devam ser testados em todas as idades acerca de sua convicção de que o seu benefício e o da cidade coincidem (412d9-e3). Tais testes consistem em submetê-los a situações em que tenderiam a abandonar suas convicções, ou seja, estamos tratando de situações simuladas que induzem a uma escolha distinta do que a educação lhes ensinou como sendo o melhor. Mais uma vez o leitor é levado a se lembrar do modelo espartano e da armadilha sobre o roubo de comida, narrada por Xenofonte. Segundo a República, esses testes forjariam situações que ofereceriam razões para alguém abandonar seus valores fundamentais. Mas isso é de fato possível (cf. 413a3-4)? Sócrates mesmo reconhece que o discernimento não abandona por si próprio opiniões que são verdadeiras (413a5-8), afinal, elas são um bem e não há motivos intrínsecos para se abandonar um bem.

São circunstâncias externas que podem causar esse fenômeno, e só o causam quando o discernimento não está bem formado. Segundo Sócrates esses casos podem ser de três tipos: nós podemos ser roubados, enfeitiçados ou violentados (413b1-2). A metáfora do roubo é traduzida em dois casos: o da persuasão, que poderia nos fazer abandonar uma boa convicção, e o do esquecimento dessa convicção (413b4-8). A violência é um caso propriamente literal: a dor e o sofrimento podem nos impor o abandono de nossas posições (413b9-11). A figura do feitiço é mais nebulosa, tendo pontos em comum com as duas outras. Trata-se de casos em que, seduzidos por um prazer, ou temerosos de algo, mudamos nossas convicções (413c1- 
4). Esses casos desenham a série de artifícios que podem ser explorados para testar o grau de convicção de alguém. O primeiro deles parece ser de natureza unicamente intelectual: testes seriam feitos por meio de argumentos e questionamentos na expectativa de que os guardiões sejam capazes de contra-argumentar opiniões incompatíveis com as suas, justificando a sua posição. Eles também devem ser capazes de memorizar suas razões e salvá-las do esquecimento.

Já os dois casos seguintes nos levam mais claramente à demanda da resistência. Do primeiro deles, em que os guardiões devem provar a sua capacidade de suportar a violência física ou moral, temos suficientes exemplos lacedemônios. Xenofonte narra como em Esparta ocasiões variadas se ofereciam para que os educandos provassem sua resistência ao chicoteamento (Xenofonte. Constituição dos Lacedemônios, 2.8.1-2.9.5; 6.1.1-6.2.6). Não temos exemplos na República de como esses testes seriam aplicados, mas talvez o episódio de Leão de Salamina narrado na Apologia nos pudesse dar alguma pista. Ali, ao ser ordenado pelo governo dos Trinta a buscar Leão de volta a Atenas para ser punido, Sócrates, ao se recusar a cumprir a ordem, exemplificaria uma situação de escolha pelos valores fundamentais em situações de medo (Platão, Apologia de Sócrates, 32c3d9). Aristóteles é certamente uma fonte mais rica de casos de teste moral, o mais célebre deles sendo o do sequestro da família como instrumento de chantagem (cf. Aristóteles, Ética a Nicômaco, 1110a4-7).

Por fim, os guardiões devem ser observados sob o teste do feitiço, um teste que Sócrates compara ao caso dos potros que, em seu processo de adestramento, são levados para o meio da balbúrdia a ver se mantêm a obediência ao seu condutor (413d7-8). Por analogia deduzimos que os guardiões devem ser expostos ao medo e ao prazer, para que se verifique se eles se deixam seduzir por propostas de resolução fácil (413c1-3). À falta de

Filosofia e Educação [RFE] - Volume 9, Número 1 - Campinas, SP

Fevereiro-Maio de 2017 - ISSN 1984-9605 - p. 131-164 
exemplos diretos, podemos supor que estejam aqui contemplados os casos da contemplação da guerra, com o risco nela envolvido, e das festas ligadas à poesia mélica, com suas iguarias, excessos alcoólicos e deleites sexuais. Como dissemos, esse teste tem em comum com o anterior a expectativa de que os guardiões, ao serem expostos a esses sentimentos, resistam. Nestes dois últimos casos, não são as capacidades intelectuais que estão em jogo, mas o grau de conviç̧ão acerca das crenças, ou, em outras palavras, o quanto são capazes de tornar os conteúdos aprendidos em ações. Aqui podemos ver que a resistência, que foi obtida pela prática da ginástica, torna-se componente indispensável do regime de vida dos guardiões. Claro, não é apenas resistência que se espera deles, mas é ela quem assegura que os governantes selecionados estejam de fato comprometidos com a cidade.

Voltamos enfim ao amor à sabedoria sem debilidade de Péricles. Platão, na República, de fato, expressa preferências lacônicas, e essas estão muito ligadas a um uso específico da ginástica para a formação do regime de resistência necessário a um guardião. Mas ele também aponta com clareza os riscos dessa escolha e os modos de evitá-los. A educação proposta na República é uma resposta ao resultado devastador da Guerra do Peloponeso. Contra o regime maleável dos atenienses, ela propõe a vida regrada pela temperança. Mas a se desejar bons guerreiros e bons governantes, é preciso que o regime extenuante dos espartanos se converta em formação da resistência equilibrada por uma longa educação filosófica. Duas regras de virtude, dois conceitos de ginástica.

\section{Conclusão}

Este trabalho procurou mostrar que há dois conceitos de ginástica envolvidos nos processos educativos propostos pela República de Platão e acabou por concluir por duas regras de virtude resultantes de cada um deles.

Filosofia e Educação [RFE] - Volume 9, Número 1 - Campinas, SP

Fevereiro-Maio de 2017 - ISSN 1984-9605 - p. 131-164 
A ginástica da temperança é uma prática individual de todos os cidadãos educados pela poesia para manter o controle de seus desejos e de seu ímpeto. Ela se justifica na recusa à figura do paidotriba como uma função especializada da cidade justa e na disputa contra a corrente dietética da medicina pela posição de poder capaz de ditar as regras da saúde e de seu lugar entre os bens humanos. Essa ginástica é uma consequência da educação poética à medida que a poesia, sobretudo a homérica, retrata práticas cotidianas que evitam os excessos da comida, da bebida e do sexo. Guiado pelas moldes educacionais dos legisladores, esse regime de vida dedica-se aos cuidados com o corpo de modo a que nunca eles se sobreponham ao exercício da função própria de cada cidadão. Esse modelo de regime passa a ser reproduzido por educandos que assim se tornam temperantes nos dois sentidos do termo definidos pela República: politicamente à medida que obedecem à regra do governo pela função própria - i.e., legitimam o melhor governo - e individualmente à medida que controlam seus apetites e seu ímpeto.

A ginástica para a coragem consiste em um treinamento atlético de período restrito, de dois a três anos ao fim da adolescência, cujo propósito é o desenvolvimento do ímpeto e a aquisição da resistência. Essa ginástica aproxima a educação proposta por Sócrates dos modelos espartanos, e não por outro motivo Platão vê riscos em sua aplicação, que devem ser mitigados por meio de um longo currículo de formação filosófica. A função educacional dessa ginástica é inversa à do caso da temperança porque se trata-se de treinamento exteriormente imposto para que se alcance a virtude de guardiões e governantes. A resistência aí obtida permite o êxito nas provações sobre sua convicção em relação à cidade ao longo de toda a sua vida. 


\section{Referências bibliográficas}

ANONYMUS LONDINIENSIS. De medicina. Edição de Daniela Manetti. Berlin: De Gruyter, 2011.

ARAÚJO, C. O belo e o fim da educação poética. In: BOCAYUVA, I., ANACHORETA, M. I. (org.) O belo na Antiguidade Clássica. Rio de Janeiro: Nau, 2016, p. 95-101.

ARISTÓTELES. Ethica Nicomachea. Edição de I. Bywater. Oxford: Oxford University Press, 1979.

BURNYEAT, M. F. Culture and Society in Plato's Republic. The Tanner Lectures on Human Values. Salt Lake City: University of Utah Press, 1999, 215-324.

DEMOS, R. Paradoxes in Plato's Doctrine of the Ideal State. Classical Quarterly, N.S. 7: 164-174 (1957)

EDELSTEIN, L., The dietetics of Antiquity. In: TEMKIN, O., TEMKIN, C. (org.). Ancient medicine, Baltimore 1967, 303-316.

FERRARI, G. R. F. The Philosopher's Antidote. In: DENHAM, A. (org.) Plato on art and beauty. New York: Palgrave Macmillan: 2012. p. 106-124.

GARDINER, E. N. Athletics of the Ancient world. Oxford: Clarendon Press, 1955.

GASTALDI, S. Paideia/mythologia. In: Vegetti, M. (org.), Platone. La Repubblica, v. II, Bibliopolis, Nápoles, 1998, 333-392.

GOLDEN, M. Sport and society in Ancient Greece. Cambridge: Cambridge University Press, 1998.

HIPÓCRATES et Corpus Hippocraticum. Oeuvres complètes d'Hippocrate. Edição de E. Littré. Paris: Baillière, 1973.

HOBBS, A. Plato and the hero: courage, manliness and the impersonal Good. Cambridge: Cambridge University Press, 2000.

IRWIN, T. Plato's Ethics. Oxford: Oxford University Press, 1995.

Filosofia e Educação [RFE] - Volume 9, Número 1 - Campinas, SP Fevereiro-Maio de 2017 - ISSN 1984-9605 - p. 131-164 
JAEGER, W. Paideia: a formação do homem grego. Trad. Artur M. Parreira. São Paulo: Martins Fontes, 1995.

KENNELL, N. M. The gymnasium of virtue: education and culture in Ancient Sparta. Chapel Hill: University of North Carolina Press, 1995.

MARROU, H. I. Histoire de l'éducation dans l'Antiquité. Paris: Seuil, 1948.

NETTLESHIP. R. L The theory of education in Plato's Republic. London, 1935.

NORTH, H. Sophrosyne: self-knowledge and self-restraint in Greek literature. Cornell University Press, 1966.

NUTTON, V. Ancient Medicine. Londres: Routledge, 2004.

PLATÃO. Platonis Rempublicam. Edição de S. R. Slings. Oxford: Oxford University Press, 2003. . Platonis opera. Edição de J. Burnet. Oxford: Clarendon Press, 1968.

PHILLIPS, E. D. Greek medicine. Londres: Thames and Hudson, 1973.

RADEMAKER, A. Sophrosyne and the rhetoric of self-restraint. Leiden: Brill, 2005.

SCHOFIELD, M. Plato Political Philosophy. Oxford: Oxford University Press, 2006.

TUCÍDIDES. Thucydidis historiae. Edição de Jones, H.S., Powell, J.E. v. 1. Oxford: Clarendon Press, 1970.

WEST, M. L. Phocylides. Journal of Hellenic Studies 98, 1978, p. 164-167. 